\title{
The International Criminal Responsibility of Governments in the Process of Globalization
}

\author{
Fazlollah Foroughi ${ }^{1} \&$ Mohammad Mirzaei ${ }^{2}$ \\ ${ }^{1}$ Faculty of Law and Political Science, Shiraz University, Shiraz, Iran \\ ${ }^{2}$ Shiraz University, Shiraz, Iran \\ Correspondence: Fazlollah Foroughi, Faculty of Law and Political Science, Shiraz University, Shiraz, Iran.
}

Received: September 4, 2016 Accepted: October 2, $2016 \quad$ Online Published: December 29, 2016

doi:10.5539/jpl.v10n1p262 URL: http://dx.doi.org/10.5539/jpl.v10n1p262

\begin{abstract}
The effects of globalization, is the globalization of responsibilities. Due to globalization, global or international criminal responsibility of the perpetrators of the crime will follow. States as one of the international actors are also not exempt from this, and the issue of criminal responsibility for them, because the rulers of communication and sensitivity to its governance principles, coupled with a lot of complexity. According to the principle of necessity, anticipate criminal responsibility of states to prevent and avoid a lot of international crimes by nature and only with the support and assistance of States in the international dimension, to establish international order and security, in line with the process of globalization is inevitable. However, with the removal of Article 19 of the draft international responsibility of the State, approved by the International Law Commission, represents the most important source of international criminal responsibility of the government, doubt the government, there is no criminal liability, it should be stressed that the elimination of the need for It does not prejudice the existence of numerous international documents and procedures, are an expression of this. The fact is that many of the behaviors that violate the rules of universal acceptance of the international community, can be done only by governments and civil responsibility only for governments to violate the rules of universal and important, in accordance with the principles of justice and international law, such as the need to maintain international peace and order of the international community, that it makes some states of the vacuum to be exploited. In order to resolve ambiguities about the criminal responsibility of the state, should the use of existing capacity of the international community, including the UN and the Security Council, to build the infrastructure and the necessary arrangements for the progressive development of these institutions, such as that for the International Criminal Court done.
\end{abstract}

Keywords: international responsibility, criminal responsibility, universal rules, the United Nations, globalization

\section{Introduction}

According to the globalization process, which has been led to the globalization of rights in general way and also to the globalization of criminal rights as individuals, their necessary requirements such as the crime, the responsibility, the penalty and the principle of justice should become a global and international perspective. Without any doubt, in any legal and international system a violation of the binding obligation is caused to a legal responsibility, so according to this, the states are one of the members of the most important of international law interfaces. Therefore the review of the international responsibility of the government has more importance and special role in international law. Because the international responsibility is a mechanism that regulated international law and this is the way of thinking that "power is with responsibility and there isn't any power without responsibility" which means that responsibility is for competency and authority that the states have achieved from their international law. Each governments will have international law because of their acts which are contrary to the law and national norms ${ }^{1}$. Actually the international responsibility is a principle which is caused to build and to organize the pillars of the international system which disregarding to it, is caused attenuation, insecurity and instability in international relations. About historical research on international system, the responsibility principle is as old as the quality of the countries (Ziaee Bigdeli, 1996, 394). However, it has existed some changes in the obligation and responsibility systems, synchronously with the globalization process

1- International law commission draft on international responsibility of states, article 2 . 
in the past decades, some obligations in criminal international law have been responsible for the states necessarily (and not to the persons). So in case of non-fulfilment of them, the government may be held accountable. In fact, the violation of the international law base on the nature of the rules violation, has various degrees and it is possible to be legal or criminal. And the responsibility of the person who violated this obligation will be different, too. Anyway, as GARCIA AMADOR "the special rapporteur of the international law commission in 1958" said: it's difficult to find an issue in international law which has a difficulty ${ }^{2}$. Furthermore, the international criminal responsibility which is caused by an obvious violation of general international rules, because it is threatening state governance principles that will be with the additional complexity. By deleting article 19 of the draft international law commission as one of the most important resources of this issue, and happening of some events at this time like MENA tragedy, the support of some governments from terrorism and Saudi crimes in YEMEN are some reasons which are caused us to check the necessity of criminal responsibility of the states. In other words, is it possible to recognize the criminal responsibility of the government in the current world order, if the answer is positive, what are the principles and manifestations of this responsibility?

This essay by admission the criminal responsibility of the governments in the globalization process of the crimes and rights, it has known it necessary for maintaining international order and security. At first, it studies on the related concepts, review and the principles and the manifestation of criminal international responsibility of governments then it will clarify some existed international procedures and it proposes the use of existing capacity on removing barriers to international law and the criminal responsibility of governments to respond to the ambiguities in that direction.

\section{The Concepts}

2.1 The responsibility: being responsible about an obligation. Committed to accountability for an act which is done and to clarify and turn to the every disadvantage which is happened ${ }^{3}$.

2.2 The international responsibility: International law responsibility is an obligation which is imposed to a government for international law to compensate any damage resulting from the act or refusal to perform the duty of the government were imported to the other government by violation of the rules of the international law (fiyouzi, 1973, 3).

2.3 The state: A crowd of people who live in the certain territory and they are the subject of a public power. The state has a legal entity in public law (Gaafari langeroudi, 2005, 314).

2.4 The international criminal responsibility of the state: Primarily, the criminal responsibility is related to the suppression of the crime and the punishment of guilty culprit (Nourbakhsh, 1381, 171) and it refer to the responsibility which is arose from crime, guilt and civil action (Ansari, 2005, 1840). So the international criminal responsibility of the state is a responsibility which is arose from the commission of international crimes by government.

\section{The Principles of International Responsibility}

Basically, three main basis for attention to criminal responsibility of the states is considered:

\subsection{The Personal Responsibility Theory}

According to this view if doing an act or preventing from doing it which is contrary to the international law, is caused by an error or fault, the international responsibility is realized (salami, 2003, 275). Therefore the existence of international responsibility arising from the act of error is the subject of international law and the prejudicial act of one state against. The other isn't international error, if it is unintentional and without malic or without neglecting reprehensible (hamidzadeh, 1384, 30). According to this theory, if the basis of the violations of international state is based on its fault so this state must be punished according to the international regulations because of its fault of negligence. In the nineteenth and early twentieth century, the international case law was affected by an error theory and numerous opinions were issued on this basis, such as the votes of the ICJ in the case of the TANG CORFU, dated 1949. At that time, in European and Latin American countries, when the international arbitral tribunals were officers to proceeding a dispute, first of all, for proof of responsibility, they were considered whether that the defendant in damage to the state or a foreigner have been had a mistake or oversights or not? 4 The error theory and its results are criticized by the followers of the subjective school of

\footnotetext{
2. Garcia Amador. F.V. "State Responsibity Some new Problems" RCADI,1958.

3. S. Henry, Campbell . Black law Dictionary. West publishing co. (1990) p. 1312.

${ }^{4}$ - For examples the nationals English has prepared a ship named ALBAMA in the case of ALBAMA during the civil war in America and they entered it to combat operations in favor of southern countries. At the end of the war, the American government which knew British
} 
international law. They believe that this theory has been given from privacy law and it can't be transferable to the international environment. More importantly, this theory considers committed forms of psychological factors which their study and measurements are difficult. So adopting to this basis will be causing complications in international relations.

\subsection{The Operation against Rights Theory}

The liability arising from acts contrary to the rights of the criterion is that the government, which violates any rule of international rules. Its responsibilities on the international stage is realized and the committed should only be assigned to the violated state. In other words, the establishment of the state's responsibility is depending on to establish the act assignment against international law. Base on this theory, the third codification of international law, the HAGUE, on 1930, says in its proposal legislation that "any kind of damage causing by the actions of the executive agencies, legislative, judicial branches of government and in violation of an international rule to foreign persons or their properties caused them to be the responsibility of the government" a big problem of an unlawful act theory is that this theory is not founded on the basis of clear criteria and order of the acts against the law is not clear. In fact, the definition of clear and decisive action against rights is not an easy task, because the concept of right is ambiguous in its self-esteem. So how does one can discover the violation or the wrong doing (fiyouzi, 1973, 20). Some believe that the attitude of the international law commission is related to this theory. And in particular the international law commission for the preparation of the first draft of text about the responsibility of the state has concluded that the responsibility of the state is realized when it violating the international commitment (Hamidzadeh, 2005, 59).

\subsection{The Danger or Objective Responsibility Theory}

According to this view, any fault in the case of the norm of international law (customary or conventional) is caused international responsibility, whether the interference element is wrong or not. On this basis the self breach and violating of an international law is involving the criminal responsibility of the states. According to this theory, the international responsibility is realized as soon as there is a casual relationship between the unlawful acts of state and any damages to other states and to their nationals, whether the government and its agents fail or not. Because living in an international community and as an independent state involving some acceptable risks which we should accept them and involving error as the only basis of the liability doesn't comply with the requirements of the international community (Davoodi, 2013, 53). Although this theory has more coordination with the factual basis of international responsibility, which is to ensure the security of international relations. It also has some problems, such as it has been said that, this theory is very remote from the reality with an absolute guarantee that the applicant gives it. Basically, it is opposite to the normal flow and the history of the international claims and giving excessive guarantees to the foreigners or their sovereign government (unlimited warranties) are against justice and fairness. The ROBERTO AGO'S report, the special rapporteur of the international law commission caused that the commission abandon the fault theory as a separate and independent responsibility element and it accepted the objective responsibility theory ${ }^{5}$. In article 1 of the international law commission proposal is emphasized about the country's international responsibility that any international fault of the state is under its responsibility. The international judicial procedures by the permanent court of international justice in the case of military or paramilitary operations in NICORAGUA against AMERICA and vice versa ${ }^{6}$, and HUNGARY against SLIVAKIA ${ }^{7}$ under the base case, is applied. The practical result was that the discussion can be said that none of these theories are acceptable as general rules and principles for always and all the times. Sometimes the international case law, has known as an adequate doing an act contrary to the international law or preventing from it for fulfillment of responsibility and in some cases it has attended to failures which is done. This ambiguity in performance, in a sense has been caused the freedom of the international courts about judicial implications and it also considers the circumstances of each case and on its special own case. So it will result in the progressive development of international law.

\section{Some Obstacle of Criminal Responsibility of Governments}

There are obstacles in order to fulfill the criminal responsibility of governments. That is most related to the legal entity of state and government in common way and in particular is related to the administrative procedure of

government, responsible for the operation ALBAMA ship, it demanded compensation. The arbitration commission decision in 1872 , base on error theory is known British government responsible for its lack of attention to the operation that violated the neutrality of its own nationals, were interfered in America's civil war.

5- The report of international law commission 1996 ، doc , A/51.10 page156

6 - ICJ, Reports, para.75, p.125, Nicaragua v. United States of America

7. Gabčíkovo-Nagymaros Project (Hungary/Slovakia) International Court of Justice Website ICJ, Reports 1997, p.7, at p.39, para.48 
government's responsibility.

\subsection{Common Barriers (The State as a Legal Person)}

The discussion about the responsibility of the legal entities is important because the state is one of the best examples of legal person. So study about the problems of criminal liability of legal person in general and also the state as a legal person in particular will be an expression and response to the criminal responsibility of the state's problems. Those who believe in the theory of criminal liability of the legal entities, raise the following arguments:

\subsubsection{Lack of Obtaining Spiritual Element for Crime of Legal Entities (Saffar, 1994, 503)}

According to the statute of the international criminal tribunal has made the existence of some spiritual and material elements condition for the realization of the crime and punish the guilty, so the lack of obtaining it for legal entity of the state will be met only for responsibility of the perpetrators and individuals. However the criminal acts of legal persons was announced because of the attention of the judges to the spiritual element in the NUREMBERG and TOKYO's court. But this was to punish their members and not to punish the legal person. As the court stated that known an organization as criminal doesn't imply that all members of the organization are criminal, but also those who have direct interference in doing acts are accused. The member of the criminal organization who are known about their goals and activities and who also have accepted their membership willingly must be punished but not all the members. Salami $(1997,208)$ with acceptance of this issue that other forms of intentional criminal attributable to the entities is occurred in case of existence of fault as the main basis for civil liability of legal entities.so this problem is little in this case8 and in fact, in a similar issue, we are faced with a variety function and process. In addition, there is a will beyond the will of every entity that has motivated them to occurrence of the action. When the member of the legal entity called why did you make this decision? Replies: "I didn't make this decision, but the company and legal organization did" and he accepts implicitly that there is a will which is above his will that causes such events in which their existence is reliable. In other words the separation of legal entity's responsibility who are consisted legal entity, which they act with supporter of legal entity, is impossible and this inseparable reason is caused punishment instead of each other and even this replacement of the punishment is taken to correct.

\subsubsection{The Impossibility of Imagining the Real Punishment for a Legal Person}

Anticipated punishment such as the imprisonment, the flogging, or the execution are for natural entities and we can't be considered them applicable for legal entities like groups (Saffar, 1994, 503). The answer is that the punishment is not only confined to physical or depriving of freedom and having some qualities of punishment such as being fearful (fear-indueing), being painful and also being humiliating is important too (Nourbakhsh, $2002,35)$. So other punishments like financial penalties, such as recording, confiscation of the property, restrict the actions and disorganization ${ }^{9}$, boycoff-intruption and military attack10 can be considered for legal entities.

\subsubsection{The Penalties of Legal Entities Is Different from the Principle of the Personal Punishment}

There is a contradiction between the criminal responsibility acceptance and the principle of the personal punishment because if some members of a legal organization were committing a crime, they must be punished neither their imaginary gathering. And if a legal entity is punished, all the people who tack place or interfere in that company or institute in any way will be punished (Ibid, 504) whereas according to religious criteria, the acceptance of the liability of legal persons will be opposed to the content of the verse "no bearer of burdens shall

${ }^{8}$ - Y.I.L.C., 1976, p. 98, para. 8; also see Gilbert Geoff, "The Criminal Responsibility of States", I.C.L.Q., 1995, Vol. 39, p.350-348

9- The article 20 of nation law, adopted 1392 say that" if the legal person based on article 43 is recognized as responsible, according to the intensity of his crime and its harmful results, he is accused to one or two of following cases and this doesn't cause to not punish the natural persons:

(A) dissolution of the legal person

(B) confiscation of property

(C) prohibition of one or more social or occupational activities permanently or for a maximum period of five years

(D) the prohibition of the public invitation to increase the capital permanently or for a maximum period of five years

(E) a ban from drawing some commercial documentation for a maximum period of five years

(C) fines

(G) the publication of the sentence by the media."

${ }^{10}$ - Article 42 of the UN Charter regarding the military action is said that: "If the Security Council consider that measures provided for in Article 41 would be inadequate or bonds proved to be inadequate, it may take such action by air, sea or land, an act which is necessary to maintain or restore international peace and security adultery, this action may include the protests, blockades and other operations by air, sea, or land forces of members of the United Nations." An obvious example of military justice may be a military strike against the international forces Iraqi government to withdraw TERMINATION's invasion of Kuwait. However, the war became a war for oil. 
bear an others burden"11 (fater, 18)

Is response, it should be said that the verse refers to non-generalized the responsibility of the doer to another and the punishment of the legal person is not compatible with the punishment of a natural person, mean that the accepted principle of the personal punishment isn't contradicted with this that others are independently responsible about interests of such per-emptive monitoring of the fulfillment of a crime?

Such as the responsibility of "reasoning" has been accepted in Islamic jurisprudence in fact the acceptance of an object is also accompanied by accepting parts of that object (Ameli, 1978, 230) and it can't accept anything and reject its rational or normal and customary necessaries (Mohaghegh damad, 1984,235 ). When the members of a legal person accepted the membership of it and they validated for such a person, so they have not excluded themselves for the consequences of such validity. In fact, since the validity of the entity and its consistency depends on their members, so the creation OF IT BY members is required its necessaries as well this rule agrees to this verse "from his ship be pays" it means that the one who was the profit-loss is noticed too.

\subsubsection{Impossible Imagination of Penalty Goals Such as Warned Criminals in Legal Entities}

To answer such a problem, it must be said what is the status of execution of the punishment is considered legislation of recidivism and respect for the sanctity of recidivism and respect for the sanctity of the society and its laws and not spiritual development and sensual person, although this is the end of all the commandments of God by establishing of such criminal regulations about legal entities and its implementation, the members of the legal person affiliated with the selection of operators and authorities in implementing and monitoring the performance of subordinates were paid more attention.

\subsection{Special Barriers of Criminal Responsibility of the States}

In addition to the foregoing cases as general objections to the institution of a legal entity, about the issue of criminal responsibility of the state as a clear example of a legal person must be said that the fundamental problem is resulted from the sensitive of government about its sovereignty and the lack of an internationally accepted reference beyond the governments to obtain and run these responsibilities. Anyway, the issue of the criminal responsibilities of the states is developing gradually and the most important challenges in the way of this progressive development, as the special rapporteur and others ${ }^{12}$ of the international law commission had gain stressed its preparations.

In the following is attended to some of these arrangements and capacities that can be considered or existed.

\subsubsection{The Legality of the Crime Principle}

Due to the removal of article 19 of the draft on responsibility of states adopted by the infer national law commission and willing of international law cannot provide an interpretation of contractual obligation or customary of governments that it expands the scope of their obligations without their next consent therefore, such that states that have accepted conventional and customary international obligations they don't admit that violation of that obligations have been known criminalized and it caused them to criminal responsibility.

This issue has been considered in the case of Danzig in 1935 by the international court of justice:"A system in with the criminal nature of an offense and its related punishment has merely been recognized to its judge, this system has been replaced for a system that this diagnosis has been possible for both the judge and the accused equally"13

In response to such a problem should be said that, however, article 19 of the international law commission act 1976 has referred expressly to some cases of international crimes and this has been omitted in 2001. But the international responsibility of the states has fundamentally frame, because, although the international law commission draft has been approved, but it hasn't become like a binding international treaty. So an appointment sources of the sentences of the states has been resulted from the sources of international law.

That under article 38 of the statute of the international court of justice are including as customary international law, international courts ideas, bilateral and multilateral international treaties, particularly general assembly resolutions. The charter of the united states, and the proposal of international of international law commission and the doctrine of international lawyers that they refer to the various mechanisms and a existed vacuum was

\footnotetext{
${ }^{11}$ For more details, see Shirazi, Seyyed Mohammad Hosseini, jurisprudential-rule Alfaqhyh, in one volume, Institute of Imam Reza (PBUH), Beirut - Lebanon, first, 1991, p. 215

12. Crawford, First Report to ILC, (A/CN. 23 4/490/ Add.3) p. 8, para. 91and Y.I.L.C., 1976, p. 98, para. 8; also see Gilbert Geoff, "The Criminal Responsibility of States", I.C.L.Q., 1995, Vol. 39, p. 345-369

${ }^{13}$ - Consistency of Certain Danzig Legislative Decrees With the Constitution of Free city.
} 
compensated in this guard while the development of agreements and international convergences are progressive development of international law and this gradual development will be one of the methods to eliminate the barriers of criminal responsibility of the states.

For examples, functions such as "aggression" in the first clause of article 19 is deleted, there is a set of manifests of the league of nations ${ }^{14}$ in which the rape is against humanity $-\mathrm{UN}$ charter ${ }^{15}$ - the statement of the definition of rape ${ }^{16}$ and the declaration on principle of friendly ${ }^{17}$ relations -the crimes against peace and human security plan ${ }^{18}$ where in some ways for the seriousness of the rape act, it has been known it as an international crime, finally, to end of this strife, in article 8 of the international criminal court review conference in Kampala is emphasized to this issue while it is redefining the fact ${ }^{19}$.

The second crime that is deleted in the third paragraph of the article 19 which had been referred to it, had been that the colonization or crimes against the right of nations about self-determination ${ }^{20}$. Although, this draft was non-binding because or it's failing to convert to the convention, but attention to its existence principles like the rights or the nations about self-determination and resolution 1514 of the general assembly ${ }^{21}$ and the vote of the international court of justice in the case of Namibia ${ }^{22}$ still remain. And it can be considered as a violation of the basic human rights and universal obligations and also it can be useful to fill this vacuum. Some others anticipated crimes in deleted 19 article had been crimes against human rights. According to the movement of criminalization of violation of human rights and humanitarian law and remove the culture of impunity gradually, there is considerable evidence of crimes about these violations which can refer to the article 3 and 5 of the international convention on the prevention and the punishment of the crime of Apartheid ${ }^{23}$ and the article 6 of the international convention on the prevention and punishment of Genocide and the article 6 of the Rome statute on the crime of the genocide. That's their issue carried out through the government's failure to prevent the mentioned crimes, basically. Such as article 1 of the convention against genocide about the responsibility of the governments in commitment to prevention (Sicilianos, 2007, 226).

Severe violations of environmental obligations are the fourth title of the crimes which is mentioned in article 19 and it should be said that despite the deletion of article 19, it has existed in other documents and procedures and it can replace like article 22 of the Stockholm ${ }^{24}$ declaration and the 1979 convention about trans boundary pollution of widespread ${ }^{25}$ air or the arbitration decision of Trail Smelter ${ }^{26}$. As the court 10 has stated ${ }^{27}$ in Nuremberg about related issues to international law and specially gross violation of international law or doing an important crime, the accusers in this case -related to crimes against humanity- commit international murder and certainly nobody, at least, claim can't claim that about the law of international murder has been tainted to the previous principle ${ }^{28}$ - base on this, today many lawyers believe that the defendant can't claim ignorance about the

\footnotetext{
${ }^{14}$ - See Y.I.L.57 C., 1976, op. cit., p. 101, para. 14.

${ }^{15}$ - Clause4. Article 2, the UN charter

${ }^{16}$ - G.A. Res., 3314 (XXIX), 14 Dec. 1974.

${ }^{17}$ - G..A. Res., 2625 (XXV), 24 Oct. 1970.

${ }^{18}$-Allain Jean \& Jones R .W.D. John, "A Patchwork of Norms: A Commentary on the 1996 Draft Code of Crimes Against the Peace \& Security of Mankind", E.J.I.L., Vol. 8, No. 1, 1997, Chapter II: Commentary, Downloaded from: http://www.ejil.org/journal/vol8/No.1/art6.html

19- see: G. A. Resolution RC/Rec.6 of 11 June 2010

${ }^{20}$ - Y.I.L.C., 1976, op. cit., p. 101, para. 15.

${ }^{21}$ - Y.I.L.C., 1976, op. cit., p. 106, para. 27.

22- Legal Consequences for States of the Continued presence of South Africa in Namibia (South West Africa) Notwithstanding Security Council Resolution 276 (1970), Advisory Opinion, ICJ Reports, 1971, p. 54.

${ }^{23}$ - International Convention on the Suppression and 79 Punishment of the Crime of Aparthied: G.A. Res., 3068 (XXVIII), 30 Nov. 1973; Reprinted \& Convention on the Prevention and Punishment of the Crime of Genocide.

${ }^{24}$ - The states are committed to working for the development of international law on liability and compensation to victims of pollution and environmental damages that are due to the activities That the areas under the jurisdiction or under their control to areas beyond their jurisdiction entered.

Declaration of the UN Conference in the Human Environment, Stockholm 1972; Reprinted in: Birnie W. Patricia \& Boyle Alan, Basic Documents on International Law \& Environment, Oxford, 1995, p. 7.

25- Convention on Long-Range Transboundary Air Pollution, 84 Geneva, Nov. 1979, in: Ibid., pp. 277-298.

${ }^{26}$-Trail Smelter Case (US v. Canada 1935) see: Madder s J.Kevin "Trail Arbit ration", E.P.I.L. 1981, Vol. 2, pp. 276-282.

${ }^{27}$-Case No. 10 issue of investigative arms factory owners and heads of the croup. The main point to prove in this case was whether the owners and bosses croup measures to strengthen the German war machine was a necessary war or not?

${ }^{28}$ - Lippman, Matthew. (1992). The Other Nuremberg: American Prosecutions of Nazi War Criminals in Occupied Germany, 3 Ind. Int'IL \& Comp.L.Rev p. 3-8
} 
criminal acts of the exercise of universal jurisdiction. Because the existence of multilateral international conventions will be a warning about the possibility of prosecuting the perpetrators of these crimes in the courts of that they are the members of these conventions ${ }^{29}$.

\subsubsection{The Legality of Penalties Principle}

In international law and in particular on the responsibility of states in international law commission isn't considered a certain punishment for the crimes set forth in article 19.and what is said in articles 51 to 54 , approved project 1976 and by deletion article 19 in articles 40 and 41 approved 2001, they aren't as a punishment but it's in order to deactivation the results from committing the crimes and its type and its quality must be already declared base.

On the principle of the legality of penalties.in response to this problem, should be said that the type, amount and the quality of the penalties are different about legal entities such as, between state and natural entities for example, by attention to the Security Council can be found some aspect of these sanctions. Although it's possible that the measures of that organization should be considered a little in terms of deprecatory punishment. But it's important for deterrent punishment's aspects. And they will be considered as different punishment in some situations. Because it is exposed the country to universal condemn and reproach as a result, according to its actual performance of that organization against the spirit of the charter of the united nations, the tendency is to accept the criminal interpretation of the operation of organizations when the security council uses some moral phrases such as "laments" and "denounce or condemn". In fact, it applies a kind of "political space" thus in addition to certain guarantees that are arose through various "actions" or "measures" which they are mentioned in charter 7. We are witnessing the emergence of other remedies -that we suggest to called them "denounce"- under the provisions of the charter and the next performance, the text of charter 7, and in particular articles 39 to $41^{30}$, measures the UN security council against any country which is violated the endanger the international security it is considered the offending act as a threat to peace (Dopoii, 1982, 450). Generally, in addition to the consent of the governments and reciprocal behavior as a traditional basic of the international law, and necessary to fulfill the promise and observance of treaties principle on the and hand and the governments recognizance principle in face of international customary laws from other hand and other laws about the relationship of the member of the society like general legal principle, precedent and legal scholars views are the necessary basic and adherence of governments from international common forms and laws (Foroughi, 2009, 24). So, the result is that to punish offenses such as crimes against humanity and important damages against human rights, should consider them as threat against peace despite of previsions issue and such articles as article $31,36,38,40,41^{31}$ the international law commission draft act of 2001 can be a prelude to enforcement of anticipated mechanisms in the other of draft or the usage of anticipated mechanisms in the character of the UN about the "necessity of moral compensation" and "non-profit" and "delayed payment" which has had a transnational nature of criminal and civil law accordingly, one of the international lawyers has stated about the punitive damages that have afflictive: (the punitive damages are irreparable and they only used to punish the reprehensible behavior and scared him will be sentenced by a jury of intimidation).

While the international case law is known to precedent and it can be said about the vote of the court of

29- Scharf, M. P. (2000-2001). Application of Treaty-Based Universal Jurisdiction to National of Non-Party States, 35 New Eng. L. Rev p. 370

${ }^{30}$ - Provisions of the UN Charter:

Article 39 of the Security Council any threat to peace - breach of the peace - or act of aggression and shall make recommendations, or decide to establish and to maintain or restore international peace and security in accordance with Articles 41 and 42 what measures should be carried out.

part of their economic relations, railway - marine - air - Zip - radio and other means of communication, and the severance of diplomatic relations.

Article 42 Should the Security Council consider that measures provided for in Article 41 would be inadequate or have proved to be inadequate, it may take such action by air, sea or land to the action that is necessary to maintain or restore international peace will begin. This action may include the protests and blockade and other operations by air forces - maritime, or land forces of members of the United Nations.

${ }^{31}$ - The draft articles of responsibility of the Government Act of 2001

Article 31:... the loss of any material or spiritual damage that is the result of internationally wrongful act

Article 36: The Government is responsible for compensation shall be assessed and compensation for any damage such as loss of profit covers Article 38: ... ensure full compensation for damages associated with delayed payment under this Chapter shall be

Article 40: (a) this season, in cases of serious violations of international responsibility obligations arising from peremptory norms of general international law is applied by a state.

(B) gross negligence or breach of such an obligation if it entails continuous administration is responsible for serious violations of the honor is Article 41: A - government should end any serious breach in the sense we work together ten 40 through legal action

(B) no state should recognize the situation resulting from Article 40 considered and any help or assistance in maintaining it and ...... 
arbitration in the case of mock about the performance of Mexico in giving loans which is faced to military threat.

"If the sentence to pay more compensation about the violation of individual rights is necessary, we need to pay it, without any doubt ${ }^{32 "}$ in the case of I'm alone, that the Canadian ships suspected to carry liquor was destroyed and sunk by the fire of the united states coast guard. So whip out punitive damages were brought explicitly in the court proceedings and this was ruling actually ${ }^{33}$.

\subsubsection{The Lack of Any Organization for Obtaining and Pursuing the Crime's of States}

About the obtaining of the criminal responsibility of states, the lack of any independent organization for pursuing and obtaining the international crimes that is known as barriers such as those which are considered for pursuing of natural individuals in international criminal court. However, at first the commission gives the responsibility about study of that issue to self-governments. And through the continuation of the dispute the subject will be given to the five- members of jury inserted in part. But, it is possible to be considered some suggestion for the use of existing capacity, such as international institutions like the united nation security ${ }^{34}$ or and the general assembly or the international court of justice established penal branches. For example, the international court of justice has been the judicial and the main element of the UN according to the article 92 of the charter. And its constitution is an inseparable part of the charter. So based on article 93 all members of the United Nations, themselves are accepting the statute, who are following the acceptance of the charter subsequently. The jurisdiction of the international court of justice hasn't any limitation according to the article 36 of the statute. In all matters that the parties refer to it like criminal issues, there has a jurisdiction. Also, according to the second part of this article, the court has jurisdiction about any legal battle between the two sides who have accepted its jurisdiction. And on any issue that is related to international law or it can ascertain the violation of the international obligation, if it is proved, so the jurisdiction of this court is unmistakable about the obtaining of the criminal background subject like violation and other related legal issues, according to the wording of the UN charter, though it may be acted in practice other wisely ${ }^{35}$.

\subsubsection{The Lack of Jurisdiction Principles and Legal Guarantees}

The existence of jurisdiction principles and legal guarantees have more attention in obtaining the crimes of states. Due to the society that is governed by the sovereignty of states, calling that state as a criminal government and using criminal and cumulative reaction are very hard and it's not advisable. Therefore, it needs to accurate guarantees that the rights of accused state to committing international crimes be guaranteed by more accurately. This important issue is neglected in the administration of criminal responsibility of state and in fact, the civil liability attributable system to the state has extended to the criminal responsibility of the state. While we need more accurate study and establish a mechanism for obtaining criminal responsibility. To answer to this problem we should consider that the principles and the jurisdiction guarantees ${ }^{36}$ aren't basically different from national principles $^{37}$ and guarantees in the national system. The principles and the guarantees of human rights inserted in various international documents are generalized to the international trials and judgments and this is also one of its obligatory arrangements. About this issue one of the international lawyers believes that generally, there is reason for fairness of universal jurisdiction's issues such as the international responsibility of the governments. And he expressed when justice is the same as the realization of the trial punishment of perpetrators and also how the universal jurisdiction and prosecute of it and also its subject are being unfair to prevent impunity for international crimes? Why should assume that justice should be the debtor of perpetrator and it is assumed that the victims implore not only for justice but also for revenge?

Why should we assume that the court that its competence is based on classic and civil relationship has more jurisdiction principles than the international courts that their competence is universal? ${ }^{38}$ By attention to this problem, it's itself a reason for acceptance of criminal responsibility of the states because there are the

\footnotetext{
${ }^{32}$ - Moke Case ( U . S . v . Mexico ) reprinted in : Moore J. B., History \& Digest of the International Arbitrations to which the United States Has Been a Party 1989 vol 4 . p.3411.

33 - Brownlie Ian , Principles of Public International Law , Oxford p 208-209.

34- Arangio-Ruiz, "The Federal Analogy\& U.N Charter Interpretation: A crucial Issue", E.J.I.L., No. 1, 1997, pp. $23-25$.

${ }^{35}$ - For more details, see Foroughi, Fazlullah and Abbasi, A., International Criminal Court's jurisdiction over the crime of aggression, Journal of Legal Studies Shiraz, 2011.

39- Crawford, op. cit., p. 8, para. 91

${ }^{37}$ - For example, the material contained in the Statute of the International Criminal Court, and the four Geneva Conventions and the International Covenant on Civil and Political Rights and other human rights documents such as the Universal Declaration of Human Rights and the European Convention on Human Rights and America

${ }^{38}$ - Eser, Albin (2003-2004). "For Universal Jurisdiction: Against Fletcher". Tulsa L. Rev, 39: 955-978
} 
acceptance of the guilt presumption and the assumption of responsibility of the states that are provided the predicted principles of fair trial and this issue interested to the acceptance of criminal responsibility of the states.

\subsubsection{The Lack of an Institution to Implement the International Sanction}

Against civil society, the development of international law isn't in a level that it can establish a transnational institution, such as those being developed Europe to be able to enforce criminal penalties against states. And it can say, now we haven't suitable institutions for the punishment of international crimes. As it has already mentioned, we can't ignore the role and the capacity of the Security Council, while all states have universal jurisdiction to deal with obvious violations of international law and norms laws, and in article 41 of the draft has been emphasized to it. So, by giving universal jurisdiction to the other countries, is known all international community as international audience of sentences and as it is said this issue interested to acceptance of the criminal responsibility of the states.

\section{The Criminal Responsibility of States Development}

\subsection{Infrastructure Second}

Until the end of second world war, base on the authenticity of sovereignty in international law, the offending governments had only limited responsibility about the international community such as compensation and restoration of the damages .and the issue of criminal responsibility of the governments didn't introduce. Because of the abstract character of the state. Therefore the obligation of the state about the violation of the international obligations is limited to compensate the damage as restitution, compensation and satisfaction. In this case, the offender state in addition to returning the situation to its restitution completely, it is also committed that it won't repeat the same international mistakes in the regulation of that time, the senior of the state officials not only ware responsible for their violations, but also the state was responsible against other governments, at the same time, only the low ranking soldiers have been accused of abuses in the war. For the first time in history in 1945, this principle was established that public officials, including senior military and political officials, prominent officials and provider of the war budget and those involved in government funding must be responsible for their obvious violations (Hermidas, 2012, 51). By the end of Second World War, the allies base on the territorial and the nationality of the victim principles initiated some investigation and they held the Nuremberg and then Tokyo trials in 1946 for the perpetrators of the international crimes. It was during this period of time that aside universal jurisdiction, criminal responsibility of the state was raised. During the same courts, they were to follow the criminal responsibility of the states' principle that has been practicable by ignorance of the immunity of state's official principle in the light of individual criminal responsibility. But, because of the foregoing reasons, such as the overlapping, the responsibility of states with the private individual officials, what actually happened was hearing persons rather than governments. Therefore the UN general assembly asked from the international law commission by a resolution $\left(177^{39}\right)$ on 21 November 1947 that it provides a code of offences against the peace and the security of mankind .This commission was provided its report by its special reporter, Spiropoulos, after three years on April 25, 1950. This report refers to the general assembly resolution (1)95 dated are December 11, 1946 base on that the united nations charter and Nuremberg statute are the discover of the international law principle, it also made differences between the international crimes and the crimes against peace and the security of mankind, and it said that:

"The crime against peace and security of mankind is including any crimes which have international element the list of crimes against the peace and security of mankind is including some cases like the actions and ignorance of the state which is entailed international responsibility that is caused by violation of international obligations and the main feature of these crimes is their political nature. The criminal responsibility in international law is one of recommended principles in the provisions of international criminal law and the statute of the court of punishment. But along criminal responsibility of individuals should be introduced an equal criminal responsibility for the states? ${ }^{40 \%}$. As a result, the commission claims that it cannot be possible to make a separate criminal responsibility along with criminal responsibility of individual for the states. Due to the various international treaties - with the few exceptions ${ }^{41}$ - haven't considered such a responsibility for the states. The commission is added: "the doctrine

\footnotetext{
39 - Code of Offences against the Peace and Security of Mankind.

${ }^{40}$ - Draft Code of Offences against the Peace and Security of Mankind, Reported by: J. Spiropoulos, Special Rapporeur of ILC, p. 258, para. 34 (d), Extract from the Yearbook of the ILC 1950, Vol. II.

${ }^{41}$ - In the context of the exceptions, for example, can be cited as follows:

- Fourth Hague Convention of 1907 on international liability for acts committed by the armed forces;

- Brussels Treaty dated May 25, 1962 and the Treaty of Vienna dated May 19, 1963 in the context of international responsibility for nuclear activities
} 
of the criminal responsibility of the states is a controversial issue. The international practice has no record of such a responsibility".

\subsection{The Modern Times}

Despite the approach of report 1950 of the commission and the Nuremberg, as the previously noted, the international law commission in draft 1976 on international responsibility of the government's plan, known as the article 19 under the less international crimes and international crimes of states, is embarked to detect the international crimes of states. Subsequently, it is finally removed in article 19 of the 2001 plan due to the various developments in the field of international criminal law and also due to the fierce resistance of states in threatening issues of their sovereignty such as criminal responsibility of the state in the current period of time. Some issues that are involved and confirmed the criminal responsibility of states can be considered as follows:

\subsubsection{The Aggravated or Partitioned Responsibility System}

Now, it should separate the criminal responsibility of the states from an ordinary responsibilities of states. The importance of this distinguishing is that the violations and international crimes haven't the same degree and this difference is required to build the different responsibility regimes and systems. The thought of criminal responsibility of the state is posed so far by international prominent lawyers and with the criticism of a single responsibility regimes which mean the responsibility of the civil compensation and offer opinions about the separation between international responsibilities according to the importance of violated obligations (Kaseseh, 2006, 345).

According to this separation, the responsibility of the governments about the fulfillment of the obligations is divided into two categories. The first is the ordinary international responsibility of states which is resulted from the violation of bilateral or multilateral ordinary obligations. Mutual obligations of states have been possessed the future of support of synallagmatic profit of states in economic , political, consular, etc. relationship and in the establishment of this responsibility, it is the decisive element of the principle of utility. Any violation of these international obligations has created a private relationship between the owner or the injured party and offender state. This issue caused it to place in the frame of the compensation regimes. But the long argument about the separation of the responsibility of the sates was introduced from the time of formulating the proposal article 19 of the international law commission and the international criminal scheme in $1976^{42}$, the article 19 is divided the international illegal acts of states into the two categories. So it had called one of them as international crimes and the other one as international delicts. The international delicts system that has inherent characteristics and it is only occurred in conjunction with the foreman and his own sacrifice. So the international crimes that are created according to the violation of the obligation of the state against all universal society is more different and severer than the first group of violations. In addition of civil dimension, it has a criminal dimension too. It will be changed into the compounding responsibility system. So the dangerous and important element is crime which is distinguished from a simple illegitimate action (Zamani and Akbarnejad, 2009, 204).

It should say that, in fact, the international law commission has explained the vote of the international court of justice in case of "Barcelona traction" by paragraphs of 2 and 4 of article 19 of the draft scheme 1980. According this vote, the court declared the concept of erga omnes obligations for the first time as: "in relation to

- Agreement dated January 27, 1967 and March 29, 1972 Convention relating to the responsibility of countries in launching objects into space; - Convention of 29 November 1969 in the field of sea pollution by oil

${ }^{42}$ - The article19 said:

(1) those that the government's actions as a violation of international obligations, are internationally wrongful act regardless of the issue is the obligation breached

(2) If compliance with an international obligation to protect the fundamental interests of the League of Nations Jinan is essential that the international community as a whole recognizes this violation as a crime is a violation of international crime

(3) In accordance with paragraph two, based on the current rules of international law, including international crime may be caused by the following:

(A) severe violation of international obligations which are of fundamental importance to maintain international peace and security, such as rape

(B) serious violations of international obligations which are to safeguard the right of people to self-determination is essential to establish or maintain such a ban enforced colonial domination

(C) serious violations of international obligations whose observance is essential to protect the environment such as the prohibition widespread contamination of the atmosphere or sea

(D) serious violations of international obligations which are essential to support humanity, such as the prohibition of slavery and apartheid mass destruction

(4) Any internationally wrongful act which is not in accordance with the second paragraph of international crime international Abuse 
international responsibilities, it is necessary to say that there should be a basic distinguish between the responsibility that the government has totally in front of the international society is assumed and the responsibilities at it have accepted about diplomatic relations in front of another state ${ }^{43}$." The recognition of the criminal responsibility of the state, according to the consequences of which would have for their rule, is met with fierce of their resistance. Finally, the international law commission is studied international responsibility arose from violations of international governments, under article 41 of the draft 2001 of state's international responsibility by replacing "the clause of violations of the obligations under peremptory norms of general international law" to instead of international crimes and international delict and returning to its former approach in $1950^{44}$. Due to removal of article19 of 1980 scheme (Hermidas, 2012, 53). Anyway the governments will have a special international responsibility at the time of violating the obligation in front of universal regulations of the convention. Respected by the international community that, of course, this responsibility wasn't a common international responsibility and due to the existence of the nature of the regulations in this convention, its violation of their regulation will be had penal aspects. While in view of logical and legal principles such as a need to proportionality between the act and its reaction, it is not right that the violation of normal regulations with natural criminal have only been open-criminal.

By attention to the votes of various court judgments in some exceptional cases and contrary to the prevailing practice in the exercise of individual criminal responsibility, we come across to some cases that they have referred to the necessity of responsibility of the governments implicitly. For example, the branch revision of the international criminal tribunal for Yugoslavia announced in case "Tadic":

It is true that probably, any some members of the group have done the criminal action materially, but the interference and the help of the other members of the group usually have a vital importance in facilitating the commission of the offense. So, because of this reason the importance of such intervention isn't less than the work of those who are actually done the desired criminal acts. In fact, these two are not different from each other ${ }^{45}$. In addition the international criminal tribunal for Yugoslavia in the case of "Furundzija" has referred to the issue of aggravated governments' responsibility when reviewing allegations of torture. The mentioned court announced about the involvement of the governments in the crime, based on the regulations of current international philanthropy law, in addition to criminal individual's responsibility and according to the official involvement of the state in torture and also the dereliction in preventing the crime action and also to obtain of punishment of the perpetrator. The responsibility of the state is realized in this case too ${ }^{46}$.

This concern has led that in case of genocide in Bosnia, the fights of Bosnia and Herzegovina against the former Yugoslavia is studied both in the court at the same time. It means that, namely, the international criminal tribunal for the former Yugoslavia, which is competent to prosecute of individuals involved in this issue and the international court of justice that is competent to handle non- criminal aspects to the wrongful acts of states. However the international justice court hasn't competence to investigate criminal claims, as soon as the criminal crime that is studied at the criminal court naturally, at the same time it is introduced to the non- criminal governmental study at international court tribunal. This shows attention which is resulted from non- criminal in international criminal law in international society. The international court tribunal in its vote 2007 about the fight of Bosnia against Yugoslavia as referring to the article 1 of the prevention of genocide and about the responsibility of the governments to prevent the crime of genocide, it has considered the actions of individuals and group affiliated with the government in this regard with responsibility of states ${ }^{47}$. To confirm this, as we were told the Geneva convention and additional protocoll have announced with similar terms, that non of liable states can't excused ${ }^{48}$ itself or other states from responsibilities which are related to itself or other state because of mentioned crimes. This convention due to having the characteristics of humanitarian law are commitment to

${ }^{43}$ - ICJ, The Case of Barcelona Traction Light and Power Company, 1970, p. 32.

44- ILC, "Report by J. Spiropoulos, Special Rapporteur of ILC on Draft Code of Offences against the Peace and Security of Mankind", in: Yearbook of the International Law Commission, Document A/CN.4/22, Volume 11, 1950.

${ }^{45}$ - ICTY, Tadic Appeals Judgment, para.191

46- ICTY, Furundzija Case No. IT-95-17/1-T, 10 December 1998, para. 142

47- ICJ Press Release, 2007/8, Application of the Convention on the Prevention and Punishment of the Crime of Genocide (Bosnia and Herzegovina v. Serbia and Montenegro), 26/Feb/2007.

${ }^{48}$ - Art. 51 of Convention (I) for the Amelioration of the Condition of the Wounded and Sick in Armed Forces in the Field, Geneva, 12 August 1949; Art. 52 of Convention (III) relative to the Treatment of Prisoners of War, Geneva, 12 August 194; Art.131 of Convention (II) for the Amelioration of the Condition of Wounded, Sick and Shipwrecked Members of Armed Forces at Sea, Geneva, 12 August 1949; Art.148 of Convention (IV) relative to the Protection of Civilian Persons in Time of War, Geneva, 12 August 1949; Art. 91 of Protocol Additional to the Geneva Conventions of 12 August 1949. 
an entire international community. So when they are violated, the violating state will have responsibility against the entire contracting states (because of the conventionality of the provisions of the convention ${ }^{49}$ ) to the entire international community ${ }^{50}$, including member states and non-member. Also the international crimes listed in article 19 of the statute of the international responsibility 1980 has been reflected in a different way in article 5 of association court. In addition to article 7 of the article of the association and expression of delict against humanity as one of the crimes under the court's jurisdiction has been referred to some cases such as genocide, eradication, enslavement, deportation, persecution, forced disappearances of persons and action of racial discrimination. The obligation of the state to abide these commitments is too enough that the UN security council as the primary responsibility of peace and international security hasn't known itself to limit to the principle of non-interference in the internal affairs of states (paragraph 7 of the article 2 of the charter) about respect to the fundamental human rights provisions within the territory of the country. Within new and forwarding understand from the charter, and in particular, the principles of human rights and the concept of peace and international security as it was done in the case if apartheid South Africa, despite of the opposition of south Africa with the intervention of the security council, it has known itself competent to intervene based on the chapter 7th nations charter and it also imposed some types of sanctions against this country. The mentioned interpretation of the Security Council about the charter means that this council rather than having the prior competent in relevant to the maintenance international peace and security, it also has a competent in maintaining the peace and security with emphasis on compliance with fundamental human rights within the countries (Hermidas. 1391, 50). Other examples of the Security Council in this regard are attempting to create a temporary criminal court in former Yugoslavia and Rwanda. While the complete separation of the individual responsibility from the government's responsibility is not correct according to that the governments have consisted of individuals and their performance. And also it can't possible to separate the individual's responsibility from government's responsibility about some crimes, because of, for example, some crimes such as violation, war crimes and some crimes against the states are done by individuals to determine the fate or the threat against the international peace but it is not possible naturally except by means of willing of the sovereignty and the power of the states. In fact, because these individuals are authorized to do the sovereignty responsibility so the proving the control of the government on their behavior is necessary. Therefore, the responsibility of the state is important in this case ${ }^{51}$. So this compound system is called as aggravated responsibility and it is resulted from the violation of the international erga omnes obligation that it is caused a public relation among the all members of international society without any attention to this whether has it been had any material and spiritual damages or not. So it can demolish the violated state. The aggravated responsibility is different from the usual responsibility of the sates on about three factors such as the intensity and the nature of the violated obligations, the fault and the damages (Kaseseh.1385, 31). While the intention and the serious fault are necessary to obtain the aggravated responsibility of offending state.

5.2.2 The Responsibility of the State in Order to Regard a Giving Guarantee of Peremptory Norms of Humanitarian

According to the commonly recognized rules, every part of involved in an armed hostility must be observed the international humanitarians rights by means of armed or restricted of its forced or by other persons and groups that in fact they face, under its order or according to its instruction and control of it and they also are guaranteed the observance (Henkerter et al., 2009, 700). The obligation to respect humanitarian law was related to the special behavior of the states and commitment to ensure compliance, is the government's commitment in getting others to comply to obey these rules. One of the features of the humanitarian law is the existence of the commitment to ensure compliance. In fact the distinguishing features of this provision with the other regulation are under the competence of the international criminal law. To give a commitment to ensure the compliance the regulations of international humanitarian ${ }^{52}$ law by another state is the direct result of the cooperation among the governments. In addition to fourfold Geneva conventions, the military manuals on many countries is including the provisions regarding the commitment to ensure the international humanitarian laws. The procedures of international organizations ${ }^{53}$, the international conferences $^{54}$ and international case law ${ }^{55}$ confirm this

\footnotetext{
49- ICJ, Nicaragua v. United States of America, Judgment of 27 June 1986, Judgment of 27 June 1986 at 114, para. 220.

${ }^{50}$ - ICTY, Kupreskic and Others, Trial Chamber, 14/Jan/2000, Case No. IT-95-16-T

${ }^{51}$ - Marina Spinedi, State Responsibility V Individual Responsibility For International Crime, EJIL,2002,v.13,No.4,p.899

${ }^{52}$ - See: military manuals of Argentina, Australia, Belgium, France, Germany, Netherlands, New Zealand, Nigeria, Philippines, Russia, Spain, Switzerland, Great Britain, United States of America

${ }^{53}$ - UN.S/Res, 822,30/Aprl/1993(Azerbaijan-Armenia); UN.S/Res,853,29/July/1993 (Azerbaijan-Armenia); G.A.Res,
} 
commitment. In fact, about the commitment to ensure the humanitarian laws, the states not only be responsible to obey this regulation, but also they undertake the obligations to provide appropriate opportunities for the implementation of the provision by others and also to deal with violator governments. Therefore the commitment to the existence guarantee. In the international humanitarian law has compensate the loss of the international criminal law by dealing with the international responsibility of sates and the provisions of humanitarian law which are observer on probable violations at the time of armed hostile activities by supervision of individuals. And it also had established that the states not only are liable to observe the provisions of the humanitarian law but also they have a double commitment to obey these provisions by others. So they have a reaction about the mentioned violation and to prohibit the offender from continuing and repeating it. And they encourage the new to the humanitarian commitments. This shows that the international law from all legal rules governing the relations among states has special attention to the guarantee and certainty of international humanitarian law.

\subsubsection{The Responsibility of States in Relation to Cooperation with Each Other}

In classical theory, the international responsibility of states, for failing to prosecute and punishment, was overseeing to the rejection of the criminal responsibility of states. On the other hand, according to this issue that some existed obligations in the international criminal law are related to the obligation of the states (such as commitment to legislative, commitment to cooperation to avoid major violation like genocide and torture), justify of the states is not conceivable from any liability in this area of international law. For example the states have a kind of commitment name commitment to cooperate against international crimes, based on their existing commitment of some international documents ${ }^{56}$. This commitment, while it is in the field of international criminal law, it also has established a responsibility to the people. The commitment to cooperate the states against the international crime has been an international legal problem based on any origins (such common or conventional commitment) on the other hand the international criminal legal regulations overseeing naturally to criminal individuals' responsibility. So the international commitment of the states against the international violation can be considered as a bridge between the international responsibility of states and criminal responsibility of individuals. The last lawyers are known this penal institution as applicable for states (Kaseseh, $2006,48)$. The state's commitment to work with other states to prosecute and to try the international criminals, not only enabling them to use universal jurisdiction over clear international crimes but also in some cases, it has commitment to use mentioned jurisdiction and to grant the competence of investigation to its internal courts. This kind of commitment to use universal jurisdiction in dealing with international crimes was as one of the main examples of international cooperation among the states and it won't be negated the competence of states parties of the Geneva Convention and additional Protocol. Some other treaties have to bind the states to exercise universal jurisdiction in relation to some crimes such as those crimes that take place during the armed conflict. The human rights commission of the united nations in several resolutions which most of them have been adopted by consensus, has been wanted the prosecute and try of suspected persons of committing violations of international humanitarian law during the conflict in Chechnya, Rwanda, Sierra Leone, Sudan and the former Yugoslavia by the cooperation with the countries ${ }^{57}$. In 2002, the commission recognized that the suspected persons to committee the war crimes should be a trial or extradite. In paragraph one of the article 41 of the responsibility of the states' draft, adopted2001, it is referred to this issue as affirmative and also in the second paragraph is referred to it as negative $\mathrm{e}^{58}$.

\footnotetext{
2677(XXV), Respect for human rights in armed conflicts, 9/Dec/1970; G.A.Res, 2852(XXVI), Respect for human rights in armed conflicts,20/Dec/1971; A/RES/2853(XXVI), Respect for human rights in armed conflicts, 20 Dec. 1971.

${ }^{54}$ - International Conference of the Red Cross, 25th International Conference, (Geneva 1986); International Conference of the Red Cross, VI of the 24th, (Manila, 1981); Conference for Security and Co-operation in Europe, Towards a Genuine Partnership in New era, Summit, Budapest, 5-6 December 1994, Budapest Document, 1994; Final declaration of the International Conference for the Protection of War Victims, Geneva, August 30- September 1, 1993.

55- ICJ, Armed Activities on the Territory of the Congo (Democratic Republic of the Congo v. Rwanda) Request for the Indication of Provisional Measures (Order of 10 July 2002).

56 - Such international instruments include the four Geneva Convention

57- UNHCHR. Res.1996/76, Situation of human rights in Rwanda; UNHCHR.Res.1995/77, Situation of human rights in the Sudan, U.N. Doc. E/CN.4/1995/77 (1995); UNHCHR.Res.1995/91, Situation of human rights in Rwanda; UNHCHR.Res., 2000/58, Situation in the Republic of Chechenya of the Russian Federation - 25 April 2000

58- Article 41 of the draft State Responsibility Act of 2001:

1. Governments must put an end to the gross violations of their interaction in Article 40

2. No State shall recognize the situation created by the violation of Article 40 and that it should not be any cooperation or assistance in maintaining the
} 


\section{Conclusion}

From the exigencies of being globalization of law process is being globalization and international of its necessities such as being globalized and internationalized the responsibilities. If this issue occurs in the field of criminal law, necessarily the crime, the justice principles, and criminal responsibility are being universal and international. In other hand, the globalization of the crime will be followed by the globalization of the criminal responsibility. According to this that states are the main elements of the global world and international law. So without any doubt, the international criminal responsibility if the states is one of the complicated and applied issues in the field of international law. This complexity is resulted from the sensitivity and the resistance of states against issues that according to their opinions is caused to threaten their sovereignty principles. Some actions are done about this issue internationally that its obvious sense has been revealed in the actions and the efforts of more than half a century of united nations international law commission in drafting the state's international responsibility. Although it had been referred to the criminal responsibility of the states clearly, in the last reform of this draft on 2001, the article 19. But it is omitted due to that mentioned barriers and sensitives. But we should say that without having any dependency on this non-necessary of this draft and some problems which were in proving this article, it has been referred to the criminal responsibility of states explicitly or implicitly in various international producers and documents. The criminal responsibility of states has been considered as the basic necessity of creating international peace and security and this is the most important cause of the existence of the criminal responsibility of the states. This issue is caused the interference of UN Security Council according to its existence philosophy which means creating international peace and security and government of souls on the United Nations charter without any dependency that is created to act due to the political acts of the council. In threatening these cases of interests have been convened (formal) some daily and temporary courts to take care of the international crimes and violations or even using some boycott and also about special cases, it has been done military acts. Meanwhile, the existence of the responsibility on legal individuals which the states are its obvious and complicated of this evidence is one of the mutual agreement cases of universal society and the lawyers. Also, in recent years, it had seen some acts of universal society in the national and international levels. So in this case it had had like approval the international conventions such as the combat conventions of Palermo organized crimes and the acceptance of groups and offender organization's responsibility. This issue shows the attraction and a gradual act of universal society to the acceptance of the criminal state's responsibility. But it should say that because of the difference of the legal and nature of individuals have been the different the kind of punishment of nature and legal persons. But these varieties in the nature of punishment, don't negate the lack of criminal responsibility of states necessarily. In addition to it is possible that some punishments are considered as punishment even though they have a compensation or civil aspects in appearance. Such as to force compensates the spiritual damages, to pay the delay payment and or to force to give the satisfaction of the injured state or person from any way of possible. The other problem is that especially the states are consist of natural elements and separation of state's acts from its natural elements will be impossible and hard in many cases. Because the least fault of states will be the lack of observation about the acts of their subset persons that themselves are the origin of the creating the responsibility. And even though many international sever crimes which called them as crimes and resulted from the violations of the erga omnes obligations are agreed by international society. Such as many proofs of aggression, the crime against Mankind, the war crimes, and genocide not only aren't possible by natural persons, but also it needs the involvement and supporter of states if it can be done and without helping and materials and spiritual states cooperation, doing it will not be possible. According to logic and legal principles such as the necessity of proportion between the act and its response, it is not erect that the violating the norms rules have usually criminal aspect they also will have the response and guarantee of the non-criminal performance. So, there isn't any doubt about the existence and development and reduction of establishing barriers necessity principles of states. And the existence performance barriers don't not train along the realization of criminal responsibility of the states about the existence necessity of this necessary international establishing. So, to result the existing performance of barriers as it has emphasized in article 93 of the UN charter, one of the responsibility of the united nation is the gradual development of rights and cooperation in international level and using existing capacity specially the facilities of the UN and especially security council and general association for adopted and compilation global conventions that are relevant to the criminal responsibility of states in which have been referred to crimes and performance guarantee and fair jurisdiction principles that are guaranteed the all rights of persons and states and the structures and performance mechanisms of these cases will be clarified are very useful. It will be useful to clear this wrong about that we are confronting with the lack void of these cases in international dimensions further more we shouldn't be forget the capacities of other international law organizations such as international criminal court, according to having natural deep structure and the form of attention to the crimes or also to change its statute by attachment of some articles about the acceptance of 
criminal responsibility of states or to establish other similar institutes.

\section{References}

Agreement dated January 27, 1967 and March 29, 1972 Convention relating to the responsibility of countries in launching objects into space.

Ameli, M. B. M.(1978). jurisprudential-rule and Alfvayd (Vol. 1). Qom, ketabforoushe mofid.

Ansari, M. (2005). degree in Private Law (Vol. 3, 1st ed.). Tehran, publisher of the mehrab.

Arangio-Ruiz. (1997). The Federal Analogy\& U.N Charter Interpretation: A crucial Issue. E.J.I.L., (1).

Article 41 of the draft State Responsibility Act of 2001.

Brownlie, I. (n.d.). Principles of Public International Law. Oxford.

Brussels Treaty dated May 25, 1962 and the Treaty of Vienna dated May 19, 1963 in the context of international responsibility for nuclear activities.

Campbell, S. H. (1990). Black law Dictionary. West publishing co.

Clause4. Article 2, the UN charter.

Code of Criminal Procedure Act of 2013.

Code of Offences against the Peace and Security of Mankind.

Conference for Security and Co-operation in Europe, Towards a Genuine Partnership in New era, Summit, Budapest, 5-6 December 1994, Budapest Document, 1994; Final declaration of the International Conference for the Protection of War Victims, Geneva, August 30- September 1, 1993.

Consistency of Certain Danzig Legislative Decrees With the Constitution of Free city.

Convention (I) for the Amelioration of the Condition of the Wounded and Sick in Armed Forces in the Field, Geneva, 12 August 1949.

Convention (II) for the Amelioration of the Condition of Wounded, Sick and Shipwrecked Members of Armed Forces at Sea, Geneva, 12 August 1949.

Convention (III) relative to the Treatment of Prisoners of War, Geneva, 12 August 1949.

Convention (IV) relative to the Protection of Civilian Persons in Time of War, Geneva, 12 August 1949.

Convention of 29 November 1969 in the field of sea pollution by oil.

Convention on Long-Range Transboundary Air Pollution, 84 Geneva, Nov. 1979.

Convention on the Prevent ion and Punishment of the Crime of Genocide.

Crawford, First Report to ILC, (A/CN. 23 4/490/ Add.3) p. 8, para. 91 and Y.I.L.C., 1976.

Davoodi, M. (2013). criminal responsibility of governments, Master Thesis, International Branch, Shiraz University.

Declaration of the UN Conference in the Human Environment, Stockholm 1972; Reprinted in: Birnie W. Patricia \& Boyle Alan, Basic Documents on International Law \& Environment, Oxford, 1995, p. 7.

Dopoii, P. M. (1982). Observations on the state supreme international crime. translated and summarized: Ali Hussain Najafi Abr abady, Law Journal of beheshti University, No. 13.

Draft Code of Offences against the Peace and Security of Mankind, Reported by: J. Spiropoulos, Special Rapporeur of ILC, p. 258, para. 34 (d), Extract from the Yearbook of the ILC 1950, Vol. II.

Eser, A. (2003-2004). For Universal Jurisdiction: Against Fletcher. Tulsa L. Rev, 39, 955-978.

Fiyouzi, R. (1973). the theory of international responsibility and political support. Tehran, Tehran University Center for International Studies.

Foroughi, F. (2009). origin and the nature of universal jurisdiction. Journal of Legal Studies Shiraz, I(3).

Foroughi, F., \& Abbass, A. (2011). International Criminal Court's jurisdiction over the crime of aggression. Journal of Legal Studies Shiraz, III(II).

Fourth Hague Convention of 1907 on international liability for acts committed by the armed forces.

G.A. Res., 2625 (XXV), 24 Oct. 1970. 
G.A. Res., 3314 (XXIX), 14 Dec. 1974.

Gaafari, L. (2005). terminology rights (11th ed.). Tehran, the ganj and danesh publishing.

Gabčíkovo-Nagymaros Project (Hungary/Slovakia) International Court of Justice Website ICJ, Reports 1997.

Garcia Amador, F. V. (1958). States Responsibility Some new Problems. RCADI.

Geoff, G. (1995). The Criminal Responsibility of States. I.C.L.Q., 39, 345-369.

Hamidzadeh, R. (2005). the international responsibility arising from acts beyond the control of their bodies. Tehran, ishragie publishing.

Henkerter, I. M., \& Dvsvaldbk, L. (2009). customary international humanitarian law, translation: Office of International Affairs branch of the Islamic Republic of Iran and the International Committee of the Red Cross, Vol. I, Rule 139, Tehran, Majd Publications.

Hermidas Bavand, D. (2012). Human rights and international responsibility of governments, "Proceedings of the First International Congress on international human rights issues, Tehran, Allameh Tabatabaei University Institute for Political and International Studies in collaboration with the Ministry of Foreign Affairs.

ICJ Press Release, 2007/8, Application of the Convention on the Prevention and Punishment of the Crime of Genocide (Bosnia and Herzegovina v. Serbia and Montenegro), 26/Feb/2007.

ICJ, Armed Activities on the Territory of the Congo (Democratic Republic of the Congo v. Rwanda) Request for the Indication of Provisional Measures (Order of 10 July 2002).

ICJ, Nicaragua v. United States of America, Judgment of 27 June 1986, Judgment of 27 June 1986 at 114, para. 220.

ICJ, Reports, para.75, p.125, Nicaragua v. United States of America.

ICJ, The Case of Barcelona Traction Light and Power Company, 1970, p. 32.

ICTY, Furundzija Case No. IT-95-17/1-T, 10 December 1998, para. 142.

ICTY, Kupreskic and Others, Trial Chamber, 14/Jan/2000, Case No. IT-95-16-T.

ICTY, Tadic Appeals Judgment, para.191.

ILC, "Report by J. Spiropoulos, Special Rapporteur of ILC on Draft Code of Offences against the Peace andSecurity of Mankind", in: Yearbook of the International Law Commission, Document A/CN.4/22, Volume 11, 1950.

International Conference of the Red Cross, 25th International Conference, (Geneva 1986).

International Conference of the Red Cross, VI of the 24th, (Manila, 1981).

International Convention on the Suppression and 79 Punishment of the Crime of Aparthied: G.A. Res., 3068 (XXVIII), 30 Nov. 1973; Reprinted.

International law commission draft on international responsibility of states, article 2.

Kaseseh, A. (2006). International Law, translated by Hossein Sharifi Taraz Kuh, First Edition, Tehran, Majd.

Legal Consequences for States of the Continued presence of South Africa in Namibia (South West Africa) Notwithstanding Security Council Resolution 276 (1970), Advisory Opinion, ICJ Reports, 1971, p. 54.

Lippman, M. (1992). The Other Nuremberg: American Prosecutions of Nazi War Criminals in Occupied Germany, 3 Ind. Int'IL \& Comp.L.Rev p. 3-8.

Marina, S. (2000). State Responsibility Vs.IndividualResponsibility For International Crime. EJIL, 13(4), 899.

Moore, J. B. (1989). History \& Digest of the International Arbitrations to which the United States Has Been a Party, vol. 4.

Nourbakhsh, R. (2002). General Criminal Law, China 6, Tehran gang and danesh Publications.

Protocol Additional to the Geneva Conventions of 12 August 1949.

Saffar, M. J. (1994). the legal entity. Tehran, publish Dana.

Salimi, A. H. (2003). the role of Islam in the development of international law. Qom, Imam Khomeini Research Institute.

Salimi, S. (1997). the phenomenon of criminal and penal criminal responsibility under international law and the 
rights of Iran. Tehran, Khayyam.

Scharf, M. P. (2000-2001). Application of Treaty-Based Universal Jurisdiction to National of Non-Party States, 35 New Eng. L. Rev.

Shirazi, S. M. H. (1991). jurisprudential-rule Alfqhyh, in one volume, China First, Beirut - Lebanon, Institute of Imam Reza (PBUH).

Sicilianos, A. (2007). lack of government responsibility to prevent and punish international crimes. translation Seyed Ali Henjy, martyr Beheshti University Law Journal, No. 46.

The report of international law commission 1996 ، doc , A/51.10 page156.

U.N. Doc. E/CN.4/1995/77.

UN.S/Res, 822,30/Aprl/1993(Azerbaijan-Armenia); UN.S/Res,853,29/July/1993 (Azerbaijan-Armenia) 2677(XXV), Respect for human rights in armed conflicts, 9/Dec/1970; G.A.Res, 2852(XXVI), Respect for human rights in armed conflicts,20/Dec/1971; A/RES/2853(XXVI), Respect for human rights in armed conflicts, 20 Dec. 1971.

UNHCHR. Res.1996/76, Situation of human rights in Rwanda.

UNHCHR.Res.1995/77, Situation of human rights in the Sudan.

UNHCHR.Res.1995/91, Situation of human rights in Rwanda.

UNHCHR.Res.2000/58, Situation in the Republic of Chechenya of the Russian Federation.

Y.I.L.57 C., 1976, op. cit., p. 101, para. 14.

Y.I.L.C., 1976, op. cit., p. 101, para. 15.

Y.I.L.C., 1976, op. cit., p. 106, para. 27.

Y.I.L.C., 1976, p. 98, para. 8.

Zamani, G., \& Hosseini Akbarnejad, H. (2009). the principle of universal jurisdiction of the International Criminal Court in the mirror. Journal of Law and Politics, (26)

Ziaee Bigdeli, M. R. (1996). public international law (10th ed.). Tehran, ganj and danesh publishing.

\section{Copyrights}

Copyright for this article is retained by the author(s), with first publication rights granted to the journal.

This is an open-access article distributed under the terms and conditions of the Creative Commons Attribution license (http://creativecommons.org/licenses/by/4.0/). 